\title{
March 1835
}

$148 \mathrm{v}$ cont'd/ Sunday March $1^{\text {st }}$.

Snowed very hard all the morning \& miserably cold. Went to the R. de Bouloi twice - cap' sermons. The Boulevards crowded with fools in masks. ${ }^{1}$

Monday $2^{\text {nd }}$.

Went to Sanson's - saw nothing new - but I hope, learned something. Saw a good case of fractured radius completely cured without deformity. He did not lecture today, nor did Chomel, I presume, on account of the Carnival. C. had a good case of dissection this morning - Pulmonary apoplexy, pneumonia, Emphysema \& a small cavity all in the same lung. Breschet was not arrived ${ }^{2}$ at $8^{1 / 2}$ so did not wait for him. Ribail on cleaning teeth, Broussais on Neuralgia - Andral continuation of Phthysis /49r/ some excellent \& most curious observations. The greasy state of the liver he said was most common in Phthysical females 4 in 5. In London \& Paris deaths from Phthysis formed a $1 / 5^{\text {th }}$ in Marseilles 1/4. In Munich there are fewer deaths from Phthysis than in any other town in Germany - because as a German ment ${ }^{d}$. afterwards to me, it was the most loft[y] town $\&$ therefore approached in temp ${ }^{\mathrm{e}}$. \& other respects the cities farther north - such as Copenhagen, in which there is the least mortality.

\section{Tuesday $3^{\text {rd }}$.}

Went to Roquet this morning - a case of Pericarditis ${ }^{3}$ - rational symptoms but not the physical present. Very bad case of peripneumony probably in stage of grey hepatization most extensive. Nothing in dead house, no lecture. Case of Pulmonary Apoplexy dead to be examined tomorrow. At two o'clock went up on the Boulevards to see the people make fools of themselves. ${ }^{4}$ I was very glad to see so few respectable persons mixing themselves up with such nonsense. It was almost entirely confined to the

\footnotetext{
${ }^{1}$ March 1 was the start of Carnival, the season immediately preceding Lent in Roman Catholic countries. It was devoted to revelry and riotous amusement of which the diarist did not approve. Carnival could last for a week and included Jeudi gras, Dimanche gras, Lundi gras and Mardi gras (Shrove Tuesday).

${ }^{2}$ The diarist is almost certainly translating literally from French in observing the non-arrival of Breschet: Il n'était pas arrivé.

${ }^{3}$ Pericarditis: inflammation of the pericardium, the membraneous sac containing the heart. If the inflammation is confined to the sac there is pain in the region of the heart. When it extends to the membrane reflected around the heart itself there is pain in the region of the heart, a feeling of anxiety, difficulty in breathing, a cough, irregular pulse, palpitation and fainting. Treatment included bleeding, purging and administration of digitalis to lessen the irritability of the heart. (Hooper, Lexicon, p. 949.)

${ }^{4}$ Yet again the diarist expresses his disapproval of public expressions and displays of amusement and enjoyment on the part of the general populace. This would seem to confirm an upbringing with some affinity to the Evangelical and Dissenting groups in England at the time.
} 
Bourgeois ${ }^{5}$ \& to a few stupid English, a party of whom dressed like foxhunters, ${ }^{6}$ I saw driving about in a carriage $\&$ four - Lord Seymour ${ }^{7}$ was there also with a coach $\&$ six distributing a quantity of sweetmeats to the crowd - it was altogether a miserable affair compared to what I expected - masked balls at all the theatres \& at many private houses.

\section{Wednesday $4^{\text {th }}$.}

Went down to the Hotel Dieu. No lectures, in the case of Pulmon ${ }^{y}$. Apoplexy a most immense cavity in the upper part of left lung half filled with clotted blood. /49v/ Pulmon ${ }^{\mathrm{y}}$. Apoplexy at the lower part. Saw this morning the flowers peeping forth in the Garden of Plants, ${ }^{8}$ symptoms of returning Spring - jovial sight - Galignani ${ }^{9}$ says this morning that yesterday's sports were the finest they have had here for some years. If so I see no reason why they $\mathbf{s h}^{\mathrm{d}}$. boast much of their Carnival - it is not worth mentioning.

\section{Thursday $5^{\text {th }}$.}

Went down to Roquet - Pericarditis case not much better, evidently Pleurisy with epanchement conjoined with it. Good case of Pneumonia in an old woman, who has at the same time chronic bronchitis - sputa not to be trusted in these cases, seldom exhibit marks of pneumonia in old persons. Good case of Emphysema very extensive, heard the Bruit de Scie. Hosp ${ }^{\text {ls }}$. are full of accidents, which occurred during the time of the Carnival. In Breschet's this morning a man was brought in with a tremendously

\footnotetext{
${ }^{5}$ Current views of the French bourgoisie among the English were a mixture of fear about their Revolutionary ideas crossing the Channel and superiority about Wellington's victory over Napoleon at Waterloo. Alfred Cobban, in his seminal work on the French Revolution, states that "Historians are generally agreed that the revolution was a bourgeois revolution". He cites the views of a number of historians on just who the bourgeois were, including that of Albert Soboul, who commented: "the bourgeoisie was diverse, it did not form a homogenous class". (Cobban, The social interpretation of the French revolution, p. 8; Soboul, Précis d' histoire de la révolution française, p. 38.)

${ }^{6}$ Dissenters in England generally disapproved of fox-hunting.

${ }^{7}$ Edward Adolphus Seymour (1804-85), 12th Duke of Somerset, was commonly called "Lord Seymour". He had entered the House of Commons as member for Okehampton in 1830 and for twenty-one years, from 1834 to 1855 , was member for Totnes. The diarist's disdain for his behaviour in Paris probably stems from Seymour being a liberal throughout his life and in 1835 he was appointed a lord of the treasury in Melbourne's administration. As he was a prominent West Country figure, the diarist may have known him by sight.

${ }^{8}$ Garden of Plants: the Jardin des Plantes was founded by Louis XIII in 1626, and several distinguished men contributed greatly to its prosperity before the appointment as superintendent of the celebrated naturalist Georges L. L. Buffon (1707-88) in 1739. At the Revolution it was feared that the garden would be involved in the general proscription but it was considered national property to which visitors of all classes were equally received, and, as it was believed to be concerned with the cultivation of medicinal plants, it survived. But it suffered from a lack of money at that time. Bonaparte, however, made considerable additions to the garden and from 1813 it flourished. (Galignani's new Paris guide, pp. 502-29.)

${ }^{9}$ Galignani's Messenger was an English newspaper published every morning at six; an afternoon edition appeared daily at 2 p.m. The diarist read it regularly in Galignani's Reading Room. This newspaper, which first appeared in 1816, was delivered in Paris and its environs before breakfast at a cost of 6 francs a fortnight or 10 francs a month. It could be obtained throughout France and in Italy, Switzerland and Germany by post. The greater part of the paper was dedicated to English news extracted from the London journals, ministerial and opposition, and contained parliamentary debates, reports from the courts of justice, commercial news, the markets, intelligence from the services and the universities, births, marriages and deaths, celebrity news, theatres, etc. The remainder of the paper contained French and other foreign news and carried reports of the French Chambers of Peers and of Deputies. (Galignani's new Paris guide, p. lxi.)
} 


\section{5-8 March 1835}

large wound on the left arm exposing the bone for nearly three inches, which was broken at the upper condyle - head was cut open - the surface of the body was very cold $\&$ there is a complete absence of "connaissance". ${ }^{10}$ Ribail terminated his course today. Saw this morning in the dead room of the $\mathrm{H}$. Dieu the body of a man stabbed in the neck during the Carnival. ${ }^{11}$

150r/ Friday $6^{\text {th }}$.

Went down to Sanson this morning - saw nothing particular in his wards - heard his lecture. Went round with Breschet - the case, I mentioned yesterday, is dead. B. has rather an uncommon case under his care now - it is that of a young man who has both elbows diseased. They are swollen about twice the natural size, soft like jelly on bending the joints or moving them, a sensation of rubbing is distinctly made manifest as tho' the cartilage were destroyed $\&$ the denuded bones rubbed against each other. ${ }^{12}$ Andral still on Phthysis.

\section{Saturday $7^{\text {th }}$.}

Went down to the Hotel Dieu to Roquet's wards - had a necrobiosis ${ }^{13}$ - woman died simply with jaundice, ${ }^{14}$ but on examination peritoneal inflam ${ }^{\mathrm{n}}$. found with consid ${ }^{1}$. $\mathrm{qt}^{\mathrm{ty}}$. of serum in the abdomen - kidneys somewhat diseased. Nothing very particular in the wards - good case of Pneumonia getting well in defiance of the opinions to the contrary of the physicians. Went to the Louvre today - but was denied admission. Must get a Billet. ${ }^{15}$

Sunday $8^{\text {th }}$.

Went to the R. de Bouloi twice - excellent sermons. $\mathbf{M}^{\mathrm{r}}$. N. uses beautiful language. I like him more \& more every time I hear him - delightful Evening - quite humorous[?].

\footnotetext{
10 "Connaissance": French for "consciousness". The man was unconscious - not surprising in view of his wounds.

${ }^{11}$ This is the diarist's only encounter with such a violent death. Such deaths must sometimes, in France as elsewhere, have been the consequence of crowd behaviour. During Carnival it would have been much easier for the murderer to escape if masked.

${ }^{12}$ This wearing away of the cartilage covering the bones which meet at joints is what occurs in osteo-arthritis, a form of which might have been the young man's condition.

${ }^{13}$ Necrobiosis: the word in the diary is much corrected and this would be an early use of the term which seems appropriate since it represents the process of decay or death - necrosis - in the body due to degeneration of the tissues.

${ }^{14}$ Jaundice: icterus, a condition characterised by yellowness of the skin and eyes. The faeces are a grey clayey colour and the urine dark. Jaundice comes on with tiredness, inactivity, loss of appetite, nausea, disturbed sleep, and back pain. It occurs mostly as a result of retention of bile from an obstruction of the gall bladder. Several species of the condition were recognised, including forms in the newborn, and in pregnant women. Others indicated the presence of gallstones, and impaired liver. The prognosis varied according to the type of jaundice, those in infants and pregnant women presenting little or no danger. The other forms were considered more problematic. Treatment included attention to nutrition and a wide range of medicines including mercury and cannabis. There were few diseases that could boast of a greater number of specific medicines and no specifics so little worthy of the name as those suggested for the treatment of jaundice. A number of earlier remedies including, for instance, the swallowing of 100 to 200 millipedes per day had long been abandoned. (Hooper, Lexicon, pp. 709-11.)

${ }^{15}$ Whilst the Louvre was open to the public on Sundays, foreigners were allowed in daily except Mondays, on presentation of their passport. (Galignani's new Paris guide, p. 501.) Perhaps he had forgotten his passport on this occasion or preferred not to carry it around with him.
} 
Monday $9^{\text {th }}$.

This is one of the most miserable mornings that I have since my arrival in Paris - the wind is very high \& it has been raining hard all day. Went down to Sanson's - he had a good case of fractured fibula, used Dupuytren's apparatus. In a case of hydrocele returned after the employment of injection for the radical cure, he has obtained complete cure by means of blisters applied to the scrotum. Engaged to take tea with Bird this evening.

Tuesday $10^{\text {th }}$.

Went down to Roquet this morning - some very good cases - pericarditis going on very well. Went into Sanson's lecture - he said it was the last time he sh ${ }^{\mathrm{d}}$. lecture. Roux /50v/ takes his place tomorrow morning, or rather takes the wards of M. Dupuytren Breschet had some good cases - he performed the operation for radical cure of hydrocele twice $-\&$ cut out a nail growing into the flesh. Went to the Louvre to see the new exposition $^{16}$ - not nearly so good as the last - indeed I only saw three or four pictures above mediocrity.

Wednesday $11^{\text {th }}$.

Went to the Hotel Dieu this morning with Sanson - he did not lecture \& left $\mathbf{S}^{\mathbf{t}}$. Marthe \& half of $S^{t}$. Jean ${ }^{17}$ for Roux who however did not come at least before Chomel's lecture. Andral lectured today on lesions of innervation of pulmonary parenchyma ${ }^{18}$ Asthma Spasmodism - which he has in two cases traced to an affection of the par vagum $^{19}$ in the neck. He commenced lesions of secretion in the cellular tissue or oedema $\&$ in the serous memb ${ }^{\mathrm{s}}$. He intends now to lecture for $1 \frac{1 / 2}{2}$ hours in order to get thro' his course. Have been reading the Bride of $\mathrm{Abydos}^{20}$ this Evening - it is a very powerful piece \& contains some excellent passages, particularly that, when Selim is surprized in the grotto, betakes himself to the shore \& there falls dead - \& again another passage pleased me very much - his invocation to Zuleika, commencing with "Thou,

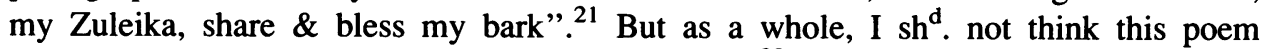
equal in point of sublimity of diction to the Giaour, ${ }^{22}$ however superior, as a man, the hero may be.

\footnotetext{
${ }^{16}$ Exposition: French for "exhibition".

${ }^{17} \mathrm{St}$. Marthe and St. Jean were two of the wards in the Hôtel Dieu.

${ }^{18}$ Parenchyma is the spongy and cellular tissue that connects parts together, and the term "innervation" rather than "nerve supply", is a way of expressing lesions in the nerve supply to the lungs.

${ }^{19}$ Par vagum: the eighth pair of cranial nerves arising from the medulla oblongata region of the brain whence the nerves proceed into the neck, thorax and abdomen.

${ }^{20}$ Byron's The bride of Abydos: a Turkish tale was first published in 1813 . It was extremely popular and several editions were produced. The wandering life of the Arabs, Tartars and Turkomans was well described in many books of eastern travels of the time. That it possessed a charm peculiar to itself cannot be denied.

${ }^{21}$ The preceding line reads: "But be the star that guides the wanderer, Thou!" (Byron, Poetical works, 1814 , p. 145.)

${ }^{22}$ Byron's The Giaour: a fragment of a Turkish tale first appeared in 1813. Not unnaturally the diarist, a young man, is moved by Byron's poetry on love.
} 
Thursday $12^{\text {th }}$.

Went down to Roquet this morning - the case in which Bruit de Scie was present, is dead - died suddenly last night, will be examined tomorrow morning. Sanson did not lecture this morning \& Roux did not visit his wards, so that I ret ${ }^{\mathrm{d}}$. home \& after reading two or three hours, went to the Louvre. The paintings are really very poor - the engravings miserable - sculpture not much better \& the curiosities uninteresting.

/51r/ Friday $13^{\text {th }}$.

Went down to the H. Dieu and saw Sanson's patients. He had a fracture of the lower jaw in $S^{t}$. Marthe, which he found considerable difficulty in reducing. The jaw was broken in two places about $1 / 2$ an inch on either side of the symphysis ${ }^{23}$ - consequently the centre portion was forcibly drawn down by the muscles, rendering it not very much unlike the small china figures one frequently sees. ${ }^{24}$ There was very considerable difficulty of reduction first from the power of the muscles \& secondly from there being scarcely sufficient space between the teeth. The latter was overcome by thrusting in a spatula \& thus forcibly pushing back the aside these obstacles - jaw was afterwards bandaged, but not so firmly as I think it $s^{d}$. have been. Also a case of laceration of [the] perinaeum ${ }^{25}-$ not connected, I hope, with the rectum - occurred a week ago in [an] accouchement. Obtained today tickets to see the Ch. of Deputies ${ }^{26}$ - went about two \& remained some time, but it was stupid work $-\mathrm{c}^{\text {ld }}$. not well understand their speakers. ${ }^{27}$ Galeries are very convenient - the Tribune ${ }^{28}$ is immediately in front of the President's Chair $\&$ the seats of Deputies arranged in a semicircle around - those who wish to speak "demandent parole" $\&$ then ascend the Tribune.

Saturday $14^{\text {th }}$.

Went down to Roquet this morning - nothing particular - returned home \& being [a] miserable day did not go out afterwards.

\footnotetext{
${ }^{23}$ Symphysis: median connection between the two halves of the lower jaw or mandible.

${ }^{24} \mathrm{He}$ means that the man looked chinless.

${ }^{25}$ Perinaeum: the region between the anus and the openings of the reproductive system. The damage referred to was possibly caused by surgical intervention with forceps.

${ }^{26}$ The Chamber of Deputies was composed of the deputies of all the Departments in France, who were chosen by the electoral colleges and nominated for seven years. The deputies had to be French, aged at least forty and be paying at least 1,000 francs annually in direct taxes. The president of the group was chosen by the king from five candidates put forward by the Deputies. The meetings of the Chamber in the Palais Bourbon were public but "strangers" could be excluded at the request of five members. The Chamber was convoked annually by the king, who could prorogue or dissolve it at pleasure. In the case of dissolution, a new chamber had to be created within three months. (Galignani's new Paris guide, pp. 27, 199.)

${ }^{27}$ This experience is not surprising. While he could follow a lecture containing familiar scientific and medical terms, many in Latin and common to both English and French, a discussion between a group of individuals, with a range of regional accents, arguing, interrupting and contradicting each other at a rapid rate would have been more difficult.

${ }^{28}$ The tribune was a raised platform or rostrum from which the deputies made their presentations.
} 


\section{5-16 March 1835}

Sunday $15^{\text {th }}$.

Attended divine Service at R. de Bouloi. A German of the name of Müller, I believe, from Bristol preached. ${ }^{29}$ His accent was very bad, ${ }^{30} \&$ I did not like him altogether much - it will be a long, very long time 'ere I hear /51v/ any one I like so well as $\mathbf{M}^{\mathrm{r}}$. Newstead, I suspect in the Evening I heard $\mathbf{M}^{\mathrm{r}}$. N. it was one of the best sermons, I think, I have ever heard him preach.

\section{Monday $16^{\text {th }}$.}

Went to the Hotel Dieu. Roux there for first time - saw nothing particular. R. did not give a Clinique, nor does he intend it, I believe, for some time. Saw a case in the Dead house, which Chomel suspected to be Arachnitis, but it turned out, typhus fever from the dissection. The "Plaques de Payer [sic]"31 were enlarged swollen, etc as well as the mesenteric glands, which are the characteristic marks of typhus according to the French pathologists. Andral today on Pericarditis - this must be one of the most difficult diseases to discover - there being not one constant symptom. The most common is dyspnoea. ${ }^{32}$ This, if considerable, $\&$ if no cause can be discovered in the lungs, $\mathrm{sh}^{\mathrm{d}}$. induce us to suspect "Pericardite". The next most common is pain or sense of constriction, still more frequently the pain is in various parts, frequently under the sternum, sometimes in the left side - in other cases in the shoulder often in the forearm or finger alone. This pain is not unlikely to be confounded with Rheumatism of the respiratory muscles, when in the side. Effusion into the cavity of the Pericard: $:^{33}$ is most easily recognised by a dull sound existing under the lower third of the sternum. But Pericarditis may kill without producing much, if any effusion of $/ 52 \mathrm{r} /$ serum. The auscultatory symptoms ${ }^{34}$ are very various $\&$ unsatisfactory - if there be not much effusion of serum - but some of lymph - there will be heard the "bruit de frottement" 35 \& at other times the "bruit de cuir neuf" or crackling of new leather. ${ }^{36}$

\footnotetext{
${ }^{29}$ The German Pastor from Bristol was presumably another itinerant evangelical preacher, possibly a Lutheran.

${ }^{30}$ The diarist never articulates any awareness of the problems the French might have in following his own rendering of their language.

31 "Plaques de Payer": Peyer's patches or glands. As the diarist explained, swelling of these glands in the wall of the small intestine was, for French pathologists - especially Broussais - a pathognomonic symptom of typhus. (See also February 20, note 48.)

${ }^{32}$ Dyspnoea: difficult respiration or distressed breathing. This is a symptom of several diseases. Chronic dyspnoea is generally accompanied by a cough. The cause lies in the chest locally or in the constitution generally. Workers in saw mills, glass cutters, stone workers or miners often suffered from the condition, as did those working in certain vapours such as acids. Dyspnoea was seen as a separate condition from asthma and a number of varieties were recognised. Recommended treatments included tranquillity of mind, gentle exercise, a mild diet excluding any food causing flatulence, and a life of regular habits. (Hooper, Lexicon, pp. 512-13.)

${ }^{33}$ Pericard: contraction for pericardium.

${ }^{34}$ Auscultatory symptoms: see Introduction, pp. 29-31.

35 "Bruit de frottement": a grating sound.

36 "Bruit de cuir neuf": the crackling sound as of new leather is used to describe the murmur which can sometimes be heard in auscultatory investigations of the heart.
} 


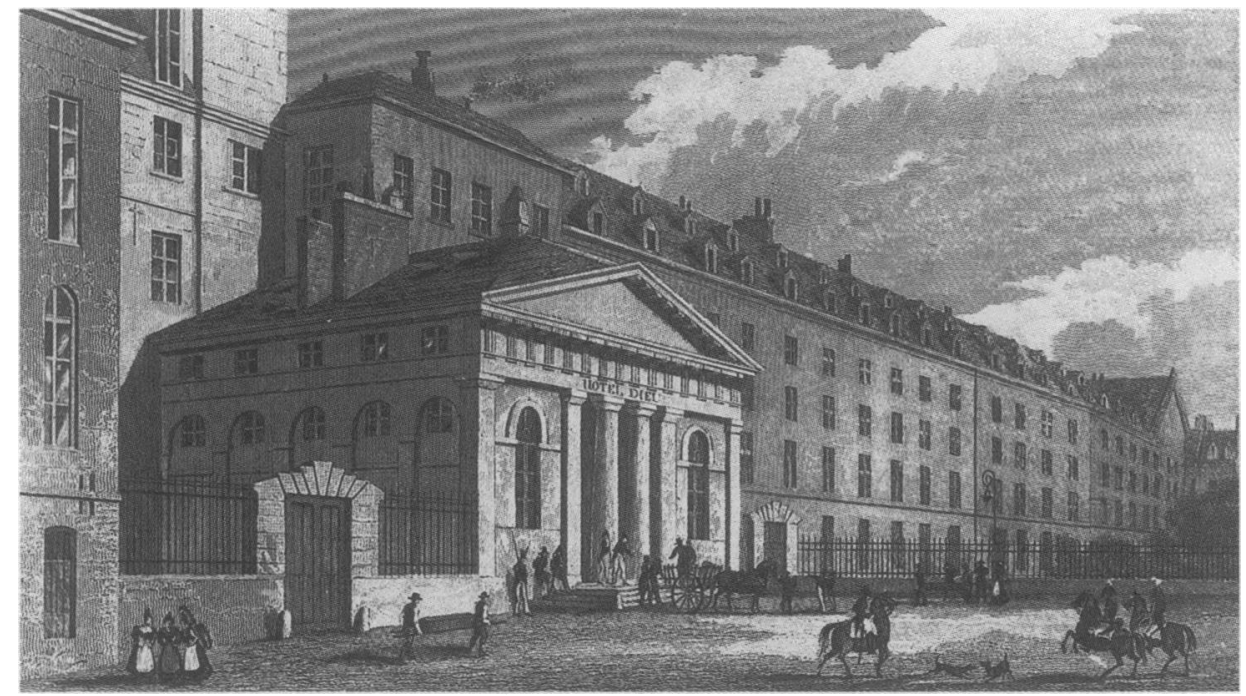

Figure 20: An early nineteenth-century view of the Hôtel Dieu from the street. Anonymous engraving. (Wellcome Library, London.)

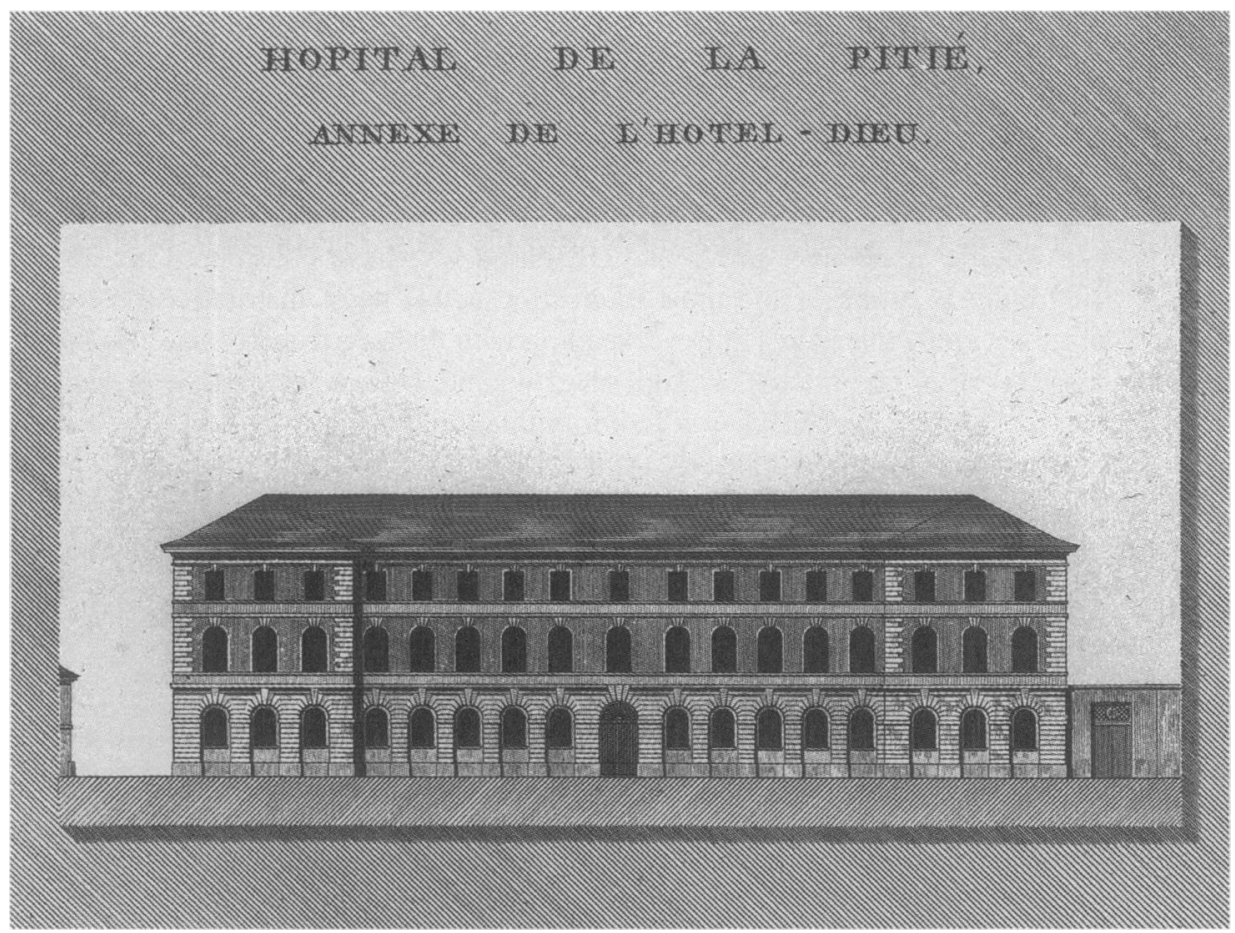

Figure 21: Façade of the Hôpital de la Pitié, which was annexed to the Hôtel Dieu. Line engraving by J. E. Thierry after H. Bassat, 1812. (Wellcome Library, London.) 
Tuesday $17^{\text {th }}$.

Went down to Roquet's this morning - two new cases - Phthysis \& Bronchitis acute \& chronic or rather acute supervening on chronic - went round with Recamier - curious fellow. There was an autopsy today, but I $\mathrm{c}^{\text {ld }}$. not remain to see it as I had an engagement to meet a gentleman at $91 / 2 .{ }^{37}$ Went to the Louvre.

Wednesday $18^{\text {th }}$.

Went round with Roux this morning - nothing particular - saw a good case of comp ${ }^{d}$. fracture of the leg under Breschet's care - produced by the wheel of an omnibus passing over it. In the case of supposed pericarditis in Recamier's ward the following were the appearances after death - pneumothorax, ${ }^{38}$ adhesions in one spot between the pleura forming a kind of separation of the cavity into two parts, a considerable effusion of puriform ${ }^{39}$ fluid in both compartments, an ulcerated or gangrenous opening at the bottom of the lung forming a communication between the bronchi \& the cavity of the pleura. There was nothing $\mathrm{a}[\mathrm{b}]$ normal ${ }^{40}$ in the heart or pericardium. The symptoms during life were excessive pain in the left side under the mamma, great agitation, dyspnoea - palpitations, very high fever - dull sound on percussion over the whole of the lower part of the left side of chest - respiration loud \& natural at upper part - towards the lower, became almost bronchial - no resonance of the voice box several times \&c. - pain diminished, as well as the agitation \& palpitation - dyspnoea \& fever increased as well as the dull sound. One morning "bruit de frottement" was heard \& in the upper part of the chest an exceedingly sonorous on percussion respiration rather less loud. The diagnosis at first was Pericarditis $152 \mathrm{v} /$ afterwards complicated with pleuritis - then pericarditis seemed cured \& pleuritis alone to remain. Afterwards accompanied with pneumothorax. I finished today Voltaire's Peter the Great. ${ }^{41}$ He was certainly one of the most extraordinary characters that ever lived indeed had he existed a few ages previously, mankind $w^{\text {ld }}$. have considered his history fabulous. Biography is probably the most interesting \& most instructive species of study - it combines all the pleasures of novel reading with that of a true history. ${ }^{42}$ Who can fail to rise from a perusal of this work without observing how true an example it presents of the correctness of the trite proverb - Labor omnia vincit? ${ }^{43}$ It $\mathrm{w}^{\text {ld }}$. have shown not a little energy of character to beat Charles $12^{\text {th }}$. \& the Turks \& to rise superior to every misfortune in such a country as Russia then was. But what shall we say of that man, who was at the same time carrying on these wars, serving in his own army as a junior officer $\&$ arising

\footnotetext{
${ }^{37}$ This is the only occasion on which he makes such a mysterious remark. To have taken precedence over his dissection work, the rendezvous must have been important.

${ }^{38}$ Pneumothorax: a condition in which there is air or gas in the thoracic cavity between the pleura, usually caused by a wound or by perforation of the lung.

${ }^{39}$ Puriform: pus-like.

${ }^{40}$ Diarist is using the French spelling of "abnormal".

${ }^{41}$ Voltaire (François Marie Arouet), Histoire de l'empire de Russie sous Pierre le Grand, 1759-1763. The diarist is more likely to have read an English translation of the work such as: The history of the Russian empire under Peter the Great, 1763.

${ }^{42}$ This diary entry and other recent ones indicate that the diarist was well read beyond his medical curriculum requirements. This was not unusual for the university physician cadre of the medical profession at the time.

${ }^{43}$ Labor omnia vincit: hard work conquers everything.
} 


\section{8-21 March 1835}

the same as others by his merit - building founding a magnificent city in a marsh on the banks of the $\mathrm{Neva}^{44}$ - building ships of war, working at them himself - afterwards acting on board of them, as his own pilot or as an inferior officer - digging immense canals, superintending them himself - introducing various arts into his empire - casting cannon - and the last, not by any means the least of his arduous labors, causing a horde of semibarbarians to throw aside the Asiatic, \& adopt the European manners? Indeed viewing him in every light, we can scarcely bring ourselves to believe him mortal. What $\mathrm{w}^{\text {ld }}$. he have been had it been his good fortune to have been born the King of a more civilized people? ${ }^{45}$ Andral lectured today on Pleuritis.

Thursday $19^{\text {th }}$.

Went down to the Hotel Dieu with Roquet - a new case of Pleuritis - very manifest considerable effusion, dull sound \&c. - excessive pain on motion or on percussion /53r/ so that as in many cases of this disease, the muscles $\&$ integuments are sympathetically affected. At Sichel's today for the first time since his return a few days since - some good cases of Sclerotite, ${ }^{46}$ Keratite $^{47}$ \&c. Walked for an hour in the Garden of Plants.

Friday $20^{\text {th }}$.

Went down to Hotel Dieu this morning - first with Sanson, then Roux \& afterwards Breschet. A good spell of it - saw a remarkable case under the care of the first, in which the conjunctiva was become thick, like the cuticle. The man had been blind from birth apparently from this cause alone - very little hope of doing him any good, I fear - M.S. ordered vapour "douches". 48 M. Chomel examined the body of a woman who died of puerperal peritonitis - in the abdomen was found a large effusion of brownish coloured liquid, with false membranes floating in it - lymph also effused on the peritoneal coat of ovaries, uterus \& liver - uterus healthy - but in one spot slight trace of purulent infiltration. Went to Robert's opening lecture on Operative Surgery. I like him very much, but his hour interferes with attendance on Sichel. Went down to Sichel's for an hour - all old cases. Guersant em gave his second lecture today - heard him - not so much to my taste as Robert. His hour interferes with Andral-however that will not matter much as A. will have finished in ten days.

Saturday $21^{\text {st }}$.

Went down to the H. Dieu with Roquet this morning. Heard amphoric respiration, ${ }^{49}$ but $\mathrm{sh}^{\mathrm{d}}$. not by myself have distinguished - very difficult to recognise the sounds met with in

\footnotetext{
${ }^{44}$ The River Neva flows through the city of St. Petersburg, which was renamed Leningrad during the Communist era. The city reverted to its original name in July 1991 following the fall of the Soviet Union. It celebrated its tercentenary in 2003.

${ }^{45}$ This "swipe" at the Russians is somewhat surprising since they, like the English, had fought against Napoleon in the recent wars.

${ }^{46}$ Sclerotite: correctly, sclerrotite, the French for scleritis or sclerotitis, inflammation of the sclerotic layer of the eyeball.

${ }^{47}$ Keratite, correctly, kératite, the French for keratitis.

${ }^{48}$ Vapour "douches": probably a reference to the air-douche applied by means of the air-press and used for dousing the eye, or cleaning out the ear.

${ }^{49}$ Amphoric respiration: a hollow sound on percussing or auscultating a pulmonary cavity.
} 
Phthysis. It is not of so much importance to distinguish them in this disease, because there are none absolutely characteristic - only serving to support the evidence of the general symptoms. Attended Robert's lecture today - like him more \& more.

$153 \mathrm{v} /$ Sunday $22^{\text {nd }}$.

Attended the Hotel Dieu this morning - nothing particular. Went to Rue de Bouloi twice. Received a letter from Clifton - Bernard ${ }^{50}$ is married. I did not expect it so soon-hope it will turn out well, but have my fears of it.

Monday $23^{\text {rd }}$.

Went to the Hotel Dieu this morning with Sanson. I observed that in the case of a stricture he covered the end of a bougie with wax, which he introduced into the urethra by pressure against the stricture. Some of the wax passed thro' \& on withdrawal exhibited a perfect cast of the "retrecissement" - went round with Roux - nothing particular - saw an interesting examination of a patient of Chomel's who died of Typhus fever. The ulcerations extended up the intestinal canal 8 feet above the ileo-caecal valve. Went to Sichel's - saw a case there of conical cornea, which he was treating with $\mathrm{Sp}^{\mathrm{ts}}$. Terebinth: ${ }^{52}$ as has been recommended by some Germans. I can't imagine how it can possibly act. Attended Guersant's lecture - he laid particular stress on the necessity of not dressing incised wounds for an hour or two after they have been made - also on leaving openings between the straps to allow serosity ${ }^{53}$ to drain out - \& lastly, which I think very proper - on the necessity of examining a wound every day - not indeed to remove the adhesive straps if we wish to produce union by first intention - but to take off the outer dressing, sponge off the dried crusts \& pus \& make every thing clean. It appears to me to be a practice which $s^{d}$. invariably $/ 54 \mathrm{r} /$ be followed.

Tuesday $24^{\text {th }}$.

Went down to the Hotel Dieu with Roger ${ }^{54}$ this morning. No new cases - saw M. Breschet's outpatients. Was particularly struck with M. B's care in examining an abscess in the

\footnotetext{
${ }^{50}$ This is probably the Dr James Bernard who had failed, despite claiming to know German, to understand a patient for M. Gibert in the Hôpital St. Louis on 12 January that year.

${ }_{51}$ Retrecissement: the correct spelling is rétrécissement, meaning stricture; see also January 20, note 126.

${ }^{52} \mathrm{Sp}^{\text {ts }}$. Terebinth: spiritus terebinthinae, spirits of turpentine. The medicament used was probably oleum terebinthinae purificatum made according to Dr Nimmo's method of agitating the oil (turpentine) with an eighth part of alcohol and pouring off the spirit. The procedure was to be repeated three or four times. (Beasley, Pocket formulary, p. 235.)

${ }^{53}$ Serosity: serum is the clear part of the blood which exudes from blood clots following the cessation of bleeding.

${ }^{54}$ Henri-Louis Roger was listed in the Almanach royal, 1831, p. 898, as a "chirurgien" (surgeon) and Warner records Williams, an American student, following in the Hôtel Dieu "the ward visits of surgeon Henri-Louis Roger" (Against the spirit of system, p. 82).
} 


\section{4-27 March 1835}

neighbourhood of the clavicle, lest it might be an aneurism. Called on Bird today - he was not at all well - afraid he is going to have an attack of smallpox. ${ }^{55}$

Wednesday $25^{\text {th }}$.

Went round with Roux - nothing particular - afterwards followed Breschet. Absolutely nothing. Roux gave his introductory Clinique today, but I did not hear it. The room was crowded - he speaks so indistinctly that it is an annoyance to be present. Called on Bird. He is much better - indeed considers himself well. He caught a slight cold a few days ago. ${ }^{56} \mathrm{At}$ Sichel's, we saw a beautiful \& very extraordinary case of cataract - central capsular surrounded by a black or brown ring with numerous rays extending to the centre produced, S: considered, by some of the colouring matter on the capsule. At Guersant's today - on ligatures ${ }^{57}$ - miserably prosy $\&$ tedious.

Thursday $26^{\text {th }}$.

Went to Roger's this morning - he gave us a lecture. We have certainly learnt a good deal from him. I shall be sorry when the course is finished. Went to the Rue des Neuves Augustines for the first time for many weeks - afterwards promenaded on the Boulevards for an hour where, it being Mi-Carême ${ }^{58}$ we had a repetition of the same follies as occurred on the Mardi Gras. Not many very good equipages \& not many very good masks - day beautiful.

Friday $27^{\text {th }}$.

Went to Hotel Dieu this morning with Roux \& afterwards to Chomel's lecture \& went round with Breschet. He had some good cases. Chomel lectured on a curious case. /54v/ A person came into the hospital a few days ago with jaundice. M. C. ordered an enema, which was given - the man complained a good deal of pain at the time $\&$ was followed by peritonitis $\&$ death. It was found on examination that the glyster pipe ${ }^{59}$ had been forced thro' the mucous membrane of the rectum \& the fluid thrown up into the peritoneal cavity. Got Broussais' certificate today - he terminated his course. Summer season commences on Wednesday - I

\footnotetext{
${ }^{55}$ Smallpox, variola: see December 26, notes 104 to 106 . Although there is no suggestion here that Bird may have contracted the disease from a patient, it was well recognised that medical students and practitioners ran the risk of being infected either by contact with patients, who were sometimes in what was described as "hospital air dense with disease producing miasmas", or when dissecting cadavers. See May 6, note 34, regarding the dangers of dissection.

${ }^{56}$ Clearly Bird had not been infected with smallpox and it is to be wondered if, following one of the stereotypes of medical students, he had exaggerated his interpretation of his own symptoms and diagnosed the worst condition.

${ }^{57}$ Ligatures: these were cotton or silk threads of various thickness, covered with white wax, for the purpose of tying cut arteries or veins, or for separating other parts, and promoting adhesion of the opposite sides of the ligature vessel to each other. Skill was needed to produce successful severance and adhesion without haemorrhage, which could be dangerous. (Hooper, Lexicon, pp. 774-5.)

${ }^{58} \mathrm{Mi}$-carême was the carnival held in the middle Thursday of Lent to celebrate the end of the first half of this period of fasting and penance.

${ }^{59}$ A glyster pipe was used for the enema.
} 
shall not attend anyone then. Guersant on application of ligatures to the radial \& ulnar arteries ${ }^{60}$ - a useful course I hope it will be. ${ }^{61}$ Had miserable dinner today.

Saturday $28^{\text {th }}$.

Went down to Roger's - had a capital case of pregnancy in which the sounds of placenta \& foetal heart were most excellently heard - but the aorta $w^{\text {ld }}$. have probably in this case misled us - as immed ${ }^{\text {ly }}$. in the front we heard a sound almost precisely similar to the loud placental souffle $^{62}$ - in one situation alone - this $M$. R. consid ${ }^{d}$. at first the placental souffle but on listening attentively we were enabled to discover the latter on the right side - it is possible there may be twins - the beatings of the foetal heart were most manifest in the hypogastric region ${ }^{63}$ - I never heard anything more distinctly - but it was necessary to listen for a considerable time \& most attentively as they were considerably masked by the sound of the aorta. About an hour afterwards I tried to hear the placental bruit ${ }^{64} \&$ could not. For this there were two reasons - first the uterus had somewhat changed its place-being much more to the left side - the woman not lying in exactly the same position as before - $/ 55 \mathrm{r} /$ secondly - there was considerable noise in the Salle - this alone $\mathrm{w}^{\text {ld }}$. probably be sufficient to account for the absence of the sound - but I think, if I remember correctly, those persons who have written on the subject have noticed this occasional absence or intermittence of the sound. Saw Breschet's outpat ${ }^{\text {ts }}$. - nothing particular - Saw Roux operate for fistula in ano - he did it very neatly - Went down to Richerand's - he was so tiresome that I $\mathrm{c}^{\text {ld }}$. not set out the form, so I ret ${ }^{d}$. home. Went down to Gerdy's \& obtained my certificate. I was at his class, I think, 3 times.

Sunday $29^{\text {th }}$.

Went to R. de Bouloi - afterwards to R. Taitbout ${ }^{65}$ to hear a $D^{r}$. Fling (or some such name) from New York, did not much like him. Went to R. de Bouloi again in the Evening.

Monday $30^{\text {th }}$.

Went to Hotel Dieu this morning with Sanson - nothing particular in the house, except a case of varicose veins of the leg in a young man, whom he is treating according to Breschet's plan for variocele of the cord. Among the outpat ${ }^{\text {ts }}$. were several good eye cases, particularly one, rather extraordinary, of protrusion (naturally) of the crystalline anteriorly into the anterior

\footnotetext{
${ }^{60}$ The radial and ulnar arteries are in the forearm.

${ }^{61} \mathrm{He}$ seems to have changed his mind about the value of Guersant's course even though earlier he was somewhat critical. See above, Friday 20 th.

${ }^{62}$ Placental souffle is one of the range of sounds produced by the movement of gas or liquid within the body organs and discernible during the procedures of auscultation and stethoscopy when investigating the heart, lungs, foetus or, as in this case, the placenta.

${ }^{63}$ The hypogastric region is the lower region of the abdomen investigated during pregnancy.

${ }^{64}$ Placental bruit: see this month, note 62 .

${ }^{65}$ The rue Taitbout had lost its ancient church of the Saint Simonians, which was closed in January 1832 by order of the authorities and taken over by the Reform Evangelical "culte" established nearby. The new church was known by the name of Église Taitbout, which it retained even when it re-located in 1840 (Hillairet, Rues de Paris, vol. 2, p. 538). It is probably to this establishment that the diarist is referring and the individual of whose name he is unsure was presumably the preacher.
} 
chamber \& partial absorption - consid ${ }^{1}$. inflam ${ }^{\mathrm{n}}$, , several cases of cataract. Saw Sanson tear out the nail of the great toe in a young man. He was some time about it, the nail being very thick \& scissors bad - employed Dupuytren's method. Went round with Breschet - he performed the same operation "d'arracher l'ongle" - has adopted the same method, but with more skilfulness. Got my certificate from Sanson today. In the Dead house saw an examination of a body with a most enormous heart. Never saw such an [sic] one before in my life. The beatings were very violent $\&$ distressing during life - but neither dyspnoea nor $155 \mathrm{v} /$ oedema - principally in the left ventricle. At Sichel's several excellent cases, particularly one of chronic Keratite of 18 months' standing of which he is not a little proud, having nearly cured it by antiphlogistic remedies alone. Two or three good examples of Irite [sic] \& Sclerotite - the latter he stated to be the most common cause of intolerance of light, \& especially when it was either Rheumatic or Scrophulous. That produced by foreign bodies etc produces it to a much less extent. He is certainly, most thoroughly acquainted with that department of the profession, which he has studied. Went to Guersant's on ligatures of the brachial, axillary \& subclavian arteries. ${ }^{66}$ Got my certificate from Andral. ${ }^{67}$

\section{Tuesday $31^{\text {st }}$.}

Went down to Roger's this morning, but he was ill \& we agreed to defer our Leçon 'till Thursday. Went round with Roux - he operated on two women, one amputation of the breast for carcinomatous tumor - very neatly performed. I was sorry to see him adopt the old method of dressing ${ }^{68}$ immediately - very bad plan I am sure, but R. was extremely particular, as indeed all the French surgeons are, in tying every artery that shewed any tendency to bleed. The other operation was for laceration of the perinaeum after accouchement - he employed the quill suture ${ }^{69}$ - three of them were sufficient. I fear the poor creature will not recover.

\footnotetext{
${ }^{66}$ The subclavian arteries are in the upper arm and shoulder region.

${ }^{67}$ The diarist has by now probably collected most of the certificates of attendance which he needs for Edinburgh.

${ }^{68}$ The diarist is referring to the method of healing by second intention, that is keeping the wound edges open post-operatively in order to allow suppuration to take place.

${ }^{69}$ Quilled sutures were used to ensure healing by second intention in cases of deep wounds, to avoid the wound healing superficially while the deeper damaged tissue still needed to suppurate to promote healing. (Cooper, Dictionary of practical surgery, pp. 1011-12.)
} 